\title{
The Role of Energy and Environmental Quality in Exploring the Economic Sustainability: A New Appraisal in the Context of North African Countries
}

\author{
Sahbi Farhani ${ }^{1,2, *}$, Mohamed Kadria ${ }^{3,4}(\mathbb{D})$ and Yosr Guirat ${ }^{5,6}$ \\ 1 Department of Economics and Quantitative Methods, Higher Institute of Finance and Taxation of \\ Sousse (ISFFS), University of Sousse, Sousse 4042, Tunisia \\ 2 QUARG UR17ES26, ESCT, Campus University of Manouba, Manouba 2010, Tunisia \\ 3 Department of Economics and Finance, College of Business and Economics, Qassim University, P.O. Box 6640, \\ Buraidah 51452, Saudi Arabia; mohamed.kadria@gmail.com \\ 4 LAREQUAD, Faculty of Economics and Management of Tunis, University of Tunis El Manar, \\ Tunis 2092, Tunisia \\ 5 Department of Business Administration, Tunis Business School, University of Tunis, El Mourouj 2074, Tunisia; \\ guiratyosr@hotmail.fr \\ 6 DEFI, Higher School of Economics and Business of Tunis, University of Tunis, Montfleury 1089, Tunisia \\ * Correspondence: sahbi.farhani@isffs.u-sousse.tn; Tel.: +216-22-833-253
}

check for

updates

Citation: Farhani, S.; Kadria, M.; Guirat, Y. The Role of Energy and Environmental Quality in Exploring the Economic Sustainability: A New Appraisal in the Context of North African Countries. Sustainability 2021, 13, 13990. https://doi.org/10.3390/ su132413990

Academic Editor:

Enrique Rosales-Asensio

Received: 25 October 2021

Accepted: 15 December 2021

Published: 18 December 2021

Publisher's Note: MDPI stays neutral with regard to jurisdictional claims in published maps and institutional affiliations.

Copyright: (C) 2021 by the authors Licensee MDPI, Basel, Switzerland. This article is an open access article distributed under the terms and conditions of the Creative Commons Attribution (CC BY) license (https:/ / creativecommons.org/licenses/by/ $4.0 /)$.

\begin{abstract}
The aim of this study is to investigate the long-term relationship between real gross domestic product (GDP), energy consumption (EC), and carbon dioxide $\left(\mathrm{CO}_{2}\right)$ emissions using: (i) fully modified ordinary least square (FMOLS) and dynamic ordinary least square (DOLS) estimates, to deal with the bias of endogeneity regressors and the countries' heterogeneity, and (ii) a pooled mean group (PMG) estimator, to involve both pooling and averaging for a dynamic specification based on the auto-regressive distributed lag (ARDL) model. Regarding five North African countries (Morocco, Algeria, Tunisia, Libya and Egypt) over the period of 1971-2014, our empirical findings seem relevant in the light of economic developments, and indicate that increased energy consumption gives rise to both GDP growth and increased $\mathrm{CO}_{2}$ emissions, as a result of more pollution. This leads us to conclude that North African countries should improve the productivity of their energy by increasing: (i) the implementation of energy-saving projects, energy conservation, energy efficiency, and energy infrastructure, while outsourcing to achieve GDP growth as well as increasing their investment in full-energy-potential projects, and (ii) the use of more renewable energy in order to mitigate emissions.
\end{abstract}

Keywords: energy consumption; $\mathrm{CO}_{2}$ emissions; economic development; North Africa; panel data analysis

\section{Introduction}

In the last few years, many states have been challenged with the agreement of producing energies to meet their economic development growth, while at the same time dealing with the issue of reducing pollution levels. One of the main reasons behind focusing on this topic is that the dynamic relationship between economic indicators, energy consumption, and carbon emissions is a desired pathway to finding the best model, which can be applied to all states and/or regions. This idea may help scientists to find theoretical studies and empirical methods that lead to a reduction in energy consumption, mitigation of emission levels, and finally an increase in the efficiency of economic policies. According to the authors of [1], there are two streams of thought: the first one is that environmental sustainability requires economic development suspension. The second one stipulates, however, that a researcher can adopt new technological methods and processes in order to save the environment and ensure economic development. In fact, this topic has been the subject of 
several studies, as many states are placing increasing importance on balancing economic growth and environmental quality. Most studies have confirmed the link between economic growth, energy use, and greenhouse gas (GHG) emissions [2-4]. Other authors have found no linking evidence between the three variables, indicating that there is no relationship between economic growth and $\mathrm{CO}_{2}$ emissions, and that only energy use Granger-causes $\mathrm{CO}_{2}$ emissions [5]. Along the same line, the authors of [6] did not find any relationship between economic growth and $\mathrm{CO}_{2}$ emissions. In the North African region, the present work observes an increase in energy demand due to rapid growth of economic activities, prior the global economic crisis.

Working on the case of Morocco, the World Bank Development Report [7] reveals that energy consumption depends on energy needs coming from imports. Concerning petroleum and oil products, Morocco imports gas and coal from Algeria. Its electricity supply hails from a quantity of imported coal (with 43\%), Spanish transmission (with 18\%), an existing quantity of fuel oil (with 15\%), natural gas imports (with 12\%), an existing quantity of hydro power (with $10 \%$ ), and an existing quantity of wind (with $2 \%$ ). To meet increasing electricity demands in the next decade, Morocco devised an investment strategy of more than $\$ 20$ billion in order to rise the installed capacity by over $6750 \mathrm{MW}$ (the installed capacity was $5292 \mathrm{MW}$, and the electricity consumption was 23.6 TWh at the end of 2009).

In the case of Algeria in 2008, gas and oil production explained $60 \%$ of the budget revenue. This value accounted for over $97 \%$ of its export earnings, and nearly $30 \%$ of the country's GDP. The domestic supply of gas reserves is about 159 Tcf. In fact, the sector of development dates back to the late 1950s. This period was characterized by the discovery of two large associated fields of gas and oil at Hassi-R'Mel and Hassi-Messaoud. As the initial target was natural gas and crude oil production, since 1961, Algeria became the first liquefied natural gas producer in the world in 1964. In 2009, oil production levels remained relatively steady at 2.13 million barrels per day $(\mathrm{bbl} / \mathrm{d})$. In the same context, consumption of domestic oil reached nearly 325,000 bbl/d, presenting approximately $15 \%$ of total production. Notably, Algeria produced 81 billion cubic meters $(\mathrm{bcm})$ of natural gas in 2009 , of which $34 \%$ was consumed and $66 \%$ was exported domestically.

In Tunisia's case, the quantities of energy resources are very limited, and are highly related to natural gas imports coming from neighboring countries. In fact, its oil production and oil reserves are also very limited. Moreover, its gas reserves are presently approximated at $2.8 \mathrm{Tcf}$. This is due to the fact that its gas production remained at $4.25 \mathrm{bcm}$ in 2009 , while its gas use added up to $5.5 \mathrm{bcm}$ (approximately 70\% headed for power); the shortage of $1.25 \mathrm{bcm}$ came from Algeria. A huge part of Algeria's electricity generation depends on natural gas (nearly 99\%), while a simple percentage depends on hydropower and wind plants (nearly 1\%). A program over the next five years intends to realize an anticipated expansion of about $3316 \mathrm{MW}$ in the installed generating capacity. This expansion depends on gas, $90 \%$ of which is offered by power generation. The new government's strategy is related to the huge use of gas in the power sector, and can be viewed in its use of coal as one of the studied plans, while nuclear is beginning to be considered for the long-term.

The case of Libya shows another view. Gas and oil production explained $95 \%$ of its export earnings, and 70\% of the total GDP. Libya's oil reserves are the largest in Africa, with 44 billion barrels, while Nigeria comes second, with 36 billion barrels, and Algeria is third, with 12 billion barrels. Oil production in Tunisia was approximately 1.88 million bbl/d in 2009. Furthermore, Libya produced nearly 15 bcm of gas in 2009, while consumption was still under $5 \mathrm{bcm}$.

For the last country, Egypt, the increased use of fossil fuels has generated a $4.6 \%$ growth in annual energy demands during the last two decades. Through the 1980s and 1990s, Egypt exported substantial quantities of oil, although its level of oil production has decreased since its peak in 1996, which was close to $935,000 \mathrm{bbl} / \mathrm{d}$, compared to the current level of about 685,000 bbl/d. Conversely, since the early 1990s, quantities of gas reserves have quadrupled, and reached 77 Tcf in 2009. These reserves represented the third highest 
quantities in Africa, after 185 Tcf in Nigeria and 159 Tcf in Algeria. Regarding this, the use of oil in both domestic consumption and energy exports has been replaced by natural gas. In 2009, the total quantity of Egypt's natural gas production reached $60 \mathrm{bcm}$, while consumption and exports quantities were, respectively, $42 \mathrm{bcm}$ and $18.3 \mathrm{bcm}$.

As shown by the World Bank Development Report [7], these five North African countries depend significantly on energy consumption. Furthermore, regional energy links have been directly related to increased energy demand. Figure 1 shows the energy interconnections of the North African region with its bordering countries.

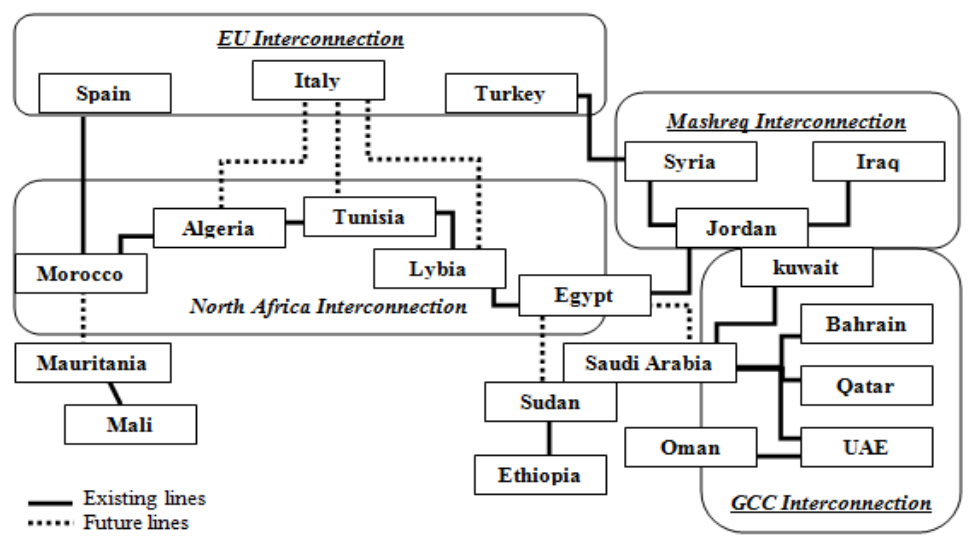

Figure 1. North Africa energy links (Source: Authors).

Additionally, the above mentioned five countries of North Africa have the highest water stress levels in the world. This situation can be explained by environmental problems related to climate change and pollution, and will likely make the region drier and hotter over the next few decades. Regional studies show that temperatures are predicted to change by varying degrees in different countries-between $1{ }^{\circ} \mathrm{C}$ and $5{ }^{\circ} \mathrm{C}$ on average-over the course of the 21st century. In 2020, mean precipitation dropped between $5 \%$ and $20 \%$ per year, compared to a reference climate from 1960-1990. To fight against climate change, the majority of countries in North Africa have made considerable efforts to attack climate change. Certainly, all countries in the region have validated the United Nations Framework Convention on Climate Change (UNFCCC) by signature and ratification. Altogether, most of them have participated, by sending their first national intercommunications, as well as validating the Kyoto Protocol by signature and ratification. Concerning climate change regional activities, Libya and Tunisia have not yet established research or policy activities linked to climate change [8].

Given the fact that GHG emissions are the first cause of climate resilience, the issue is therefore the achievement of economic development under the condition of environmental protection. To deal with that, the present paper attempts to study the link between economic growth, energy consumption, and carbon emissions in the five North African countries mentioned above, during the period of 1971-2014. In general, the empirical analyses and adopted models in the literature depend highly on the expansion level and economic growth of the selected states.

Knowing the delicate environmental situation of the selected five North African countries, and using sharp methodology, the contribution of this paper consists of setting up a model of these countries regarding the issue of ensuring economic development under the condition of environmental protection.

The remainder of the paper is ordered as follows. The Section 2 presents a literature review. Data and empirical methodology are detailed in Section 3. Econometric results and interpretations are presented in Section 4. Conclusion and policy implications are stated in Section 5. 


\section{Literature Review}

The existing literature has taken a long time to build a rich and convincing bibliography explaining the consequences endured by the environment for several decades. Several empirical studies have shown that environmental quality depends on several determining factors. The main factor explaining the growth of pollution rates $\left(\mathrm{CO}_{2}\right.$ emissions) is economic growth. Indeed, this dynamic relationship has been discussed in several empirical and theoretical studies. Generally, if the relation is linear, then the effect of the added value of growth is very positive at a certain level. Other empirical papers have cited a non-linear growth-pollution relation, inspired through testing the environmental Kuznets curve (EKC) applicability. The results differ depending on the sample and/or the methodology of the empirical study.

A wide range of econometric techniques and procedures (auto-regressive distributed lag (ARDL), vector auto-regressive (VAR), vector error correction (VEC), cointegration techniques, the Granger causality test, etc.) have been utilized in several surveys examining the connection between $\mathrm{CO}_{2}$ emissions, GDP, and EC; however, the observed results and implications are clearly determined by the underlying variables, data, and empirical methodology of a country or a region.

The authors of [9], for example, studied the link between income inequality, $\mathrm{CO}_{2}$ emissions, and temporal shifts based on panel data from North, Central, and South America, Western and Eastern Europe, Oceania, Japan, Asia, and Africa over the period of 1960-1990. Their empirical methodology included EKC and Granger causality tests. The final findings showed a Granger causality running from $\mathrm{CO}_{2}$ to GDP in North America, along with Western and Eastern Europe, while in Central and South America, Oceania, and Japan the results show a Granger causality running from GDP to $\mathrm{CO}_{2}$. Finally, they found bidirectional causality between GDP and $\mathrm{CO}_{2}$ in both Asia and Africa. In another study [10], researchers examined a decomposition formula related to the effects of changes in population, economic growth (GDP), energy intensity indicators, energy consumption, the share of fossil fuels, and the carbon intensity of fossil fuel combustion in OECD countries during the period of 1982-1997. Their findings showed that emissions growth (GHG, $\mathrm{CO}_{2}$ ) was mainly driven by economic growth (GDP). In the same countries, over the period of 1975-1990, The author of [11] revealed that including energy consumption (EC) in the regression results in a negative link between GDP and $\mathrm{CO}_{2}$ emissions, which is contrary to earlier findings. The authors of [12] also examined the case of OECD countries, and proved that there is limited support for a turning point in the link between GDP and per capita EC, and/or $\mathrm{CO}_{2}$ emissions. These findings led to an observation of the absence of any turning point in the link between GDP and either EC or $\mathrm{CO}_{2}$ emissions for non-OECD countries during the period of 1973-1997. By using vector error correction model (VECM) cointegration techniques, and the Granger causality test, when studying the case of France during the period of 1960-2000, the author of [2] found a Granger causality running from GDP to EC, as well as from GDP to $\mathrm{CO}_{2}$, in the long term, and running from EC to GDP in the short term. Similarly, in the case of the USA, the authors of [5] concluded that income growth (GDP) does not Granger-cause $\mathrm{CO}_{2}$ emissions in the long term, though EC does. Consequently, GDP by itself cannot be considered a solution to environmental problems from 1960-2004. The authors of [13] developed a panel VAR model, using the GMM-SYS approach, for 82 countries over the period of 1972-2020. Moreover, they divided their work into three income groups (low, middle, and high). In the case of the low-income group, the authors did not find a causal relationship between GDP and EC. In the case of the middle-income groups (lower and upper middle), they proved that GDP positively causes EC; however, in the high income group, they concluded that GDP negatively causes EC. The authors of [14] also provided VECM techniques, the Granger causality test, and EKC applicability in Central America during the period of 1971-2004. Their results showed that EC had a positive and statistically significant impact on $\mathrm{CO}_{2}$ emissions, while real GDP revealed the existence of an inverted U-shape pattern aligned with the EKC hypothesis, in terms of long-term equilibrium. The short-term equilibrium showed the presence of a 
unidirectional causality running from EC and real GDP to emissions; additionally, there was a bidirectional causality between real GDP and EC. In the long-term, a bidirectional causality between EC and $\mathrm{CO}_{2}$ emissions seemed to be present. In another type of work, the authors of [15] examined the strong relationship between $\mathrm{SO}_{2}$ (sulfur emissions), $\mathrm{PM}_{10}$ (particulate matter less than $10 \mu \mathrm{m}$ in diameter), $\mathrm{CO}_{2}$ emissions, and GDP in Turkey in 1992-2001, as well as in a panel of 58 provinces of Turkey in 1968-2003. Their empirical results showed that a monotonically rising relationship between $\mathrm{CO}_{2}$ and GDP was detected, in the long-term, by time series analysis, while for the 58 provinces the panel data analysis showed an N-shaped relationship between $\mathrm{SO}_{2}$ and $\mathrm{PM}_{10}$ emissions. The authors of [16] also considered the case of Turkey over the period of 1960-2000, and concluded that $\mathrm{CO}_{2}$ emissions Granger-cause EC, but the reverse is not true. The lack of a long term causal relationship between GDP and $\mathrm{CO}_{2}$ emissions plays a vital role in reducing $\mathrm{CO}_{2}$ emissions. This means that Turkey does not need to refrain from economic growth. The authors of [17] also examined the case of Turkey during the period of 1968-2005, using the ARDL bounds testing approach to cointegration. In their results, they revealed no Granger causality between $\mathrm{CO}_{2}$ emissions per capita, EC per capita, and real GDP per capita. In another work, the authors of [18] showed that VECM and Granger causality tests, in China, revealed a long-term Granger causality running from GDP to $\mathrm{EC}$, as well as from $\mathrm{EC}$ to $\mathrm{CO}_{2}$, over the period of 1960-2007. The author of [19] also examined the case of China over the period of 1981-2006, using multivariate cointegration Granger causality tests. He concluded that a long-term policy target of lowering $\mathrm{CO}_{2}$ emissions and $\mathrm{EC}$ will lead to a closed-form interaction, at the expense of the economy (GDP). Furthermore, pursuing economic growth solely for the sake of GDP will raise both $\mathrm{CO}_{2}$ emissions and $\mathrm{EC}$, as well as resulting in negative consequences for global climate change. Due to the heterogeneity of 18 countries, as well as data frequency (Germany: 1970-2005, Hungary: 1965-2005, the rest of countries: 1960-2005), the authors of [20] used the ARDL bounds testing approach to cointegration, ECM based on the Granger causality test, and EKC applicability. They proved that the bounds F-test of cointegration, in the case of European economies, showed the existence of a long-term relationship between real GDP, real GDP squared, $\mathrm{CO}_{2}$ emissions, and EC in only Germany, Switzerland, Iceland, Denmark, Portugal, Greece, and Italy. The estimated parameters were likewise stable during the sample period, according to the cumulative sum and squares tests. Furthermore, the authors of [21] studied the Granger-causal link between real GDP, EC, and $\mathrm{CO}_{2}$ emissions for the Commonwealth of Independent States during the period of 1992-2004. Their empirical results revealed that the dynamics in the short term showed a unidirectional causality from real GDP and EC, respectively, to $\mathrm{CO}_{2}$ emissions, along with a bidirectional causality between EC and real GDP. There was a bidirectional causality between $\mathrm{EC}$ and $\mathrm{CO}_{2}$ emissions in the long term. In the same vein, the short- and the long-term Granger causality results, based on [22], showed that the connection between pollution $\left(\mathrm{CO}_{2}\right.$ and $\left.\mathrm{SO}_{2}\right)$ and income (GDP) in Tunisia, in 1961-2004, showed a unidirectional causality running from GDP to the environment. The findings of [23] show that the long-term GDP elasticity was less than the short-term GDP elasticity in developing countries in 1980-2004. Thus, it is clear that a country's $\mathrm{CO}_{2}$ emissions decrease as its GDP has increases. In addition, the long-term elasticity of GDP is lower than the short-term, though only for panels in the Middle East and South Asia, which suggests that $\mathrm{CO}_{2}$ emissions have fallen with a rise in GDP. In another way, the author of [24] examined the same methodology for MENA countries during the period of 1980-2009, and found that there was a bi-directional Granger causality between EC, $\mathrm{CO}_{2}$ emissions, and GDP in both the short- and the long-term. The findings of this study supported the vital role of oil consumption in the increase of MENA countries' economic growth. In newly industrialized countries (NIC), the author of [25] used panel cointegration and Granger causality tests for the period of 1971-2007. Furthermore, he stated that the outcomes of the Granger causality test show that there is no evidence of a long-term causal association between $\mathrm{CO}_{2}$ emissions, EC, GDP, trade openness and urbanization. However, there are short-term unidirectional causal connections from trade openness and GDP to $\mathrm{CO}_{2}$ emis- 
sions, from trade openness and urbanization to GDP, from trade openness to urbanization, and from GDP to EC. The authors of [26] studied Asian-Pacific countries during the period of 1971-2005, and showed that there were long-term equilibrium links between EC, GDP, and $\mathrm{CO}_{2}$ emissions. In 28 provinces in China, the authors of [27] used panel cointegration and panel VECM techniques to indicate that there were bidirectional causality relationships between $\mathrm{CO}_{2}$ emissions and EC, as well as between EC and GDP. The results also show that, in the long-term, EC and GDP cause $\mathrm{CO}_{2}$ emissions, while GDP and $\mathrm{CO}_{2}$ emissions cause EC. In addition, four other studies provide insight on the link between GDP, EC, and $\mathrm{CO}_{2}$ emissions. First, study [3], of the case of MENA countries during the period of 1981-2005, examined bootstrap panel unit roots, plus cointegration techniques, and showed that, in the long-term, EC had a positive significant impact on $\mathrm{CO}_{2}$ emissions, and GDP exhibited a GDP squared (GDP2) relationship with $\mathrm{CO}_{2}$ emissions. Second, study [28], also of MENA countries, applied a panel empirical analysis to investigate the link between EC, GDP, and $\mathrm{CO}_{2}$ emissions for 15 MENA countries over the period of 1973-2008. Its findings revealed that EC did not present a causal relationships with GDP and/or $\mathrm{CO}_{2}$ emissions in the short-term. However, a unidirectional causal relationship, running from GDP and $\mathrm{CO}_{2}$ emissions to EC, was detected in the long-term. Third, study [29], of thirty sub-Saharan African countries, examined the effect of EC and $\mathrm{CO}_{2}$ emissions on GDP, as well as financial development, over the period of 1980-2008. The results showed that high EC gave rise to increased GDP and financial development in the studied economies, though it also resulted in increased pollution, as more $\mathrm{CO}_{2}$ emissions are produced. Finally, the authors of [30] used the Granger causality test to show a one-way causal link running from GDP to $\mathrm{CO}_{2}$ emissions, as well as from EC to $\mathrm{CO}_{2}$ emissions, in both short- and long-term analysis, in Pakistan during the period of 1971-2009. They also found that trade openness may mitigate $\mathrm{CO}_{2}$ emissions in the long-term, though it is still negligible in the short-term.

The authors of [31] investigated the link between $\mathrm{CO}_{2}$ emissions, GDP, and coal consumption in both China and India over the period of 1965-2009. Empirical findings proved the existence of a unidirectional causality running from GDP to $\mathrm{CO}_{2}$ emissions in China. In addition, causal links between $\mathrm{CO}_{2}$ emissions and coal consumption, as well as between GDP and coal consumption, were detected. The findings also confirmed the presence of a bidirectional causality link between GDP and $\mathrm{CO}_{2}$ emissions, plus a unidirectional causality running from GDP to coal consumption, only in India.

Along the same lines, using VECM and the cointegration approach, the authors of [32] studied the short- and long-term causality between three variables: environmental degradation, economic growth, and oil use, in the Philippines during the period of 1965-2012. The results confirmed the presence of a bidirectional causality between oil use and economic growth, as well as between oil use and $\mathrm{CO}_{2}$ emissions, added to the presence of unidirectional causal link running from $\mathrm{CO}_{2}$ emissions to economic growth.

In 2016, the authors of [33] analyzed the impact of environmental degradation, energy use, trade, and human capital on economic growth in selected higher- $\mathrm{CO}_{2}$ emission economies, namely China, the USA, India, and Japan, during the period of 1971-2013. Using the fully modified ordinary least squares (FMOLS) method, the panel results revealed that $\mathrm{CO}_{2}$ emissions and energy use had significant negative impacts on economic growth, while trade and human capital tended to have significantly positive impacts on economic growth. However, in individual analyses across countries, the panel estimate suggests that $\mathrm{CO}_{2}$ emissions have a significant positive relationship with economic growth in China, Japan, and the USA, while the relationship was found to be significantly negative in the case of India.

More recently, applying panel analysis, the authors of [34] examined the relationship between coal consumption, GDP, and $\mathrm{CO}_{2}$ emissions in 10 countries (India, China, Germany, Russia, United States, South Africa, Australia, South Korea, Poland, and Japan) over the period of 1992-2009. The findings proved that $\mathrm{CO}_{2}$ emissions and coal consumption have a long-term relationship with GDP. 
Based on the stochastic impacts by regression on population, affluence and technology (STIRPAT) modeling framework, the author of [35] explored the link between disaggregated energy consumption, economic growth, and $\mathrm{CO}_{2}$ emissions in five emerging market economies, namely Brazil, Russia, India, China, and South Africa (BRICS), during the period of 1992-2016. In the long-term, capital, labor, and non-renewable energy consumption positively affected economic growth. Contrarily, the impact of renewable energy consumption on economic growth was found be positive, though statistically insignificant. Moreover, population, per-capita income, and non-renewable energy consumption were found to increase emissions, whereas renewable energy consumption decreased emissions. Therefore, along with proper emission controls, BRICS countries should design and implement effective support policies, so as to ensure economic growth along with environmental sustainability.

Based on the work presented in [36], a bootstrap ARDL model was used in order to study the nexus between GDP, coal consumption, and $\mathrm{CO}_{2}$ emissions in both China and India from 1969 to 2015. The authors reported the absence of a long-term link between those three variables in both countries.

Likewise, the authors of [37] employed panel analysis to explore the relationship between GDP, gas consumption, and environmental degradation in a group of 14 AsianPacific countries during the period of 1970-2016.

In order to better understand the qualitative systematic review and meta-analysis of the nexus $\mathrm{CO}_{2}$ emissions-economic growth, the authors of [38] used a method called preferred reporting items for systematic reviews and meta-analyses (PRISMA). The results showed that this nexus provided some reasons for policy options that led to reduced emissions by imposing limiting factors on economic growth. They also showed that a bidirectional causality exists; as far as economic growth increases or decreases, further $\mathrm{CO}_{2}$ emissions are stimulated in higher or lower levels, and, consequently, a potential reduction of emissions should have an adverse influence on economic growth.

Recently, using the panel ARDL model for African OPEC countries, covering the period of 1970-2016, the authors of [39] found that, in the long-term, economic growth had an impact on $\mathrm{CO}_{2}$ and methane emissions. In the short-term, economic growth had an impact on methane, but not on $\mathrm{CO}_{2}$ emissions. However, energy consumption did not have an impact on $\mathrm{CO}_{2}$, nitrous oxide, or methane emissions in either the short- or long-term.

More recently, the authors of [40] studied the effects of carbon emissions, rainfall, temperature, inflation, population, and unemployment on economic growth in Saudi Arabia during the period of 1990-2019. Using the ARDL approach to cointegration, the authors found that: (i) Saudi Arabia can still achieve higher economic growth without effectively addressing its unemployment problem; (ii) $\mathrm{CO}_{2}$ emissions had a negative effect on the economic growth, (iii) rainfall showed a negative cointegrated link into the economic growth, while temperature showed a positive cointegrated link into the economic growth; and (iv) the effects of inflation and population on economic growth varied in the short-term, while in the long-term the effects were similar and positive.

Also in 2021, the authors of [41] gained novel insights into the complex role of sustainable development goals (SDGs) in shaping productivity growth. Using dynamic panel regressions on data collected from 138 countries between 2000 and 2017, the authors found that: (i) rising temperatures negatively affected growth and mitigated the impact of other SDGs on growth, (ii) $\mathrm{CO}_{2}$ emissions had a U-shaped relationship with growth, (iii) life expectancy negatively influenced growth, and (iv) food security positively impacted growth.

\section{Data and Empirical Methodology}

\subsection{Data}

Annual data for real GDP (GDP) (measured in constant 2010 US\$ per capita), energy consumption (EC) (measured in $\mathrm{kg}$ of oil equivalent per capita), and carbon dioxide emissions $\left(\mathrm{CO}_{2}\right)$ (measured in metric tons per capita) were collected from the recent World Bank Development Indicators online databank. Data were selected for the period 
of 1971-2014. A panel analysis was used, and considered a sample composed of North African countries, namely Egypt, Libya, Tunisia, Algeria, and Morocco. All data were transformed into natural logarithms to minimize heterogeneity. Descriptive statistics for the variables in our panel analysis are presented in Table 1.

Table 1. Descriptive statistics of North African countries (1971-2014).

\begin{tabular}{cccc}
\hline & LNGDP & LNEC & LNCO $_{\mathbf{2}}$ \\
\hline Mean & 7.997949 & 6.612999 & 0.845502 \\
Median & 7.984966 & 6.562463 & 0.776946 \\
Maximum & 9.398046 & 8.117768 & 2.302338 \\
Minimum & 6.610536 & 5.196845 & -0.729667 \\
Std. Dev. & 0.643226 & 0.737948 & 0.771590 \\
\hline Skewness & 0.188839 & 0.409725 & 0.352818 \\
Kurtosis & 2.437432 & 2.437763 & 2.316229 \\
Jarque-Bera & 4.591235 & 9.876092 & 9.654640 \\
Probability & 0.100699 & 0.007169 & 0.008008 \\
\hline Sum & 1919.508 & 1587.120 & 202.9205 \\
Sum Sq. Dev. & 98.88363 & 130.1515 & 142.2889 \\
\hline Observations & 220 & 220 & 220 \\
\hline Cross sections & 5 & 5 & 5 \\
\hline
\end{tabular}

Notes: LN, natural logarithm form; GDP, real gross domestic product per capita; EC, energy consumption per capita; $\mathrm{CO}_{2}$, carbon dioxide emissions per capita.

\subsection{Econometric Methodology}

Three objectives were proposed for empirical training. The first was to study the stationarity characteristics of individual datasets in panel samples, employing a combination of panel unit root tests ([42] "LLC"; [43] "IPS"; [44] "MW"; and [45] "Hadri"). The second aim involved inspecting whether there is a long-term association between the underlining variables, using various cointegration tests, such as [46,47]'s and [48]'s panel cointegration tests. The third objective consisted of estimating the parameters of the long-term link using suitable approaches (FMOLS, DOLS, and PMG), including the VECM technique, in order to determine the Granger-causality links.

\subsubsection{Panel Unit Root Tests}

The authors of [42] suggested an ADF-based panel of the [49] test, assuming that all panel units are cross-sectionally independent, and that the autoregressive coefficient dynamics are homogeneous. They investigated the following equation:

$$
\Delta W_{i t}=\alpha_{i}+\beta_{i} W_{i, t-1}+\gamma_{i} t+\sum_{j=1}^{k} \theta_{i j} \Delta W_{i, t-j}+\varepsilon_{i t}
$$

where $\Delta$ indicates the first forward difference operator; $W_{i t}$ is the endogenous variable; $\varepsilon_{i t}$ is white-noise disturbance with a variance of $\sigma^{2}$; and $\mathrm{I}=1,2, \ldots, \mathrm{N}$ and $\mathrm{t}=1,2, \ldots, \mathrm{T}$ indicate countries and time, respectively. The LLC test suggests the null hypothesis $H_{0}: \beta_{i}=0$ against the alternative hypothesis $H_{1}: \beta_{i} \prec 0$, for all " $i$ ", where the last hypothesis corresponds to $W_{i t}$ being stationary. The test is based on the t-statistic $t_{\beta_{i}}=\hat{\beta}_{i} / \sigma\left(\hat{\beta}_{i}\right)$ (where $\hat{\beta}_{i}$ is the OLS estimate of $\beta_{i}$ in Equation (1) and $\sigma\left(\hat{\beta}_{i}\right)$ is its standard error). Generally, the LLC test shows that the panel analysis may provide a significant result with finite samples. Thus, a new panel version, given by Equation (2), can be considered, where $\hat{\beta}_{i}$ has been restricted by conserving it in the identical across countries as follows:

$$
\Delta W_{i t}=\alpha_{i}+\beta W_{i, t-1}+\gamma_{i} t+\sum_{j=1}^{k} \theta_{i j} \Delta W_{i, t-j}+\varepsilon_{i t}
$$


The [43] test, noted by IPS, is based on the mean group analysis, which uses the mean of the $t_{\beta_{i}}$ statistics from Equation (1) to execute the following $\bar{Z}$ statistic:

$$
\bar{Z}=\sqrt{N}[\bar{t}-E(\bar{t})] / \sqrt{V(\bar{t})}
$$

where $\bar{t}=\frac{1}{N} \sum_{i=1}^{N} t_{\beta_{i}}, E(\bar{t})$, and $V(\bar{t})$ are, respectively, the mean and variance of each $t_{\beta_{i}}$ statistic, and engendered by simulations. $\bar{Z}$ converges in distribution to the standard normal.

The MW technique of [44] is based on a combination of the test-statistics' $p$-values for each individual unit root test for cross-sections, where $p_{i}$ defines this $p$-value. Then, under the null hypothesis, which indicates the presence of a unit root for all cross-sections, the techniques of this test propose the asymptotic result as:

$$
P_{M W}=-2 \sum_{i=1}^{N} \ln \left(p_{i}\right) \rightarrow \chi^{2}(2 N)
$$

This test applies the same hypotheses used by IPS.

The KPSS test of $[45,50]$ attempts to study the residuals that existed in the individual OLS regressions. Including both constant and trend, the test comes to derive estimates from the following equation:

$$
w_{i t}=\alpha_{i}+\lambda_{i} t+e_{i t}
$$

Taking into account the stationarity that existed under the null hypothesis, the asymptotic result is obtained via:

$$
Z=\frac{\sqrt{N}(L M-\xi)}{C} \rightarrow N(0,1)
$$

where $L M=\frac{1}{\hat{\sigma}_{e}^{2}} \frac{1}{N T^{2}} \sum_{i=1}^{N} \sum_{t=1}^{T} S_{i, t}^{2} S_{i, t}=\sum_{j=1}^{t} \hat{e}_{i, j}$ is the cumulative sum of the residuals, and $\hat{\sigma}_{e}^{2}=\frac{1}{N T} \sum_{i=1}^{N} \sum_{t=1}^{T} \hat{e}_{i, t}^{2}$ is the estimator of $\sigma_{e}^{2}$. The author of [45] also proposes two cases:

$$
\left\{\begin{array}{c}
\xi=1 / 6 \text { and } C=1 / 45 \text {, if the model only includes constant } \\
\xi=1 / 15 \text { and } C=11 / 6300 \text {, if the model includes both constant and trend }
\end{array}\right.
$$

The Monte Carlo simulations examined in [45] seem to provide more precise results when $\mathrm{T}$ and $\mathrm{N} \rightarrow \infty$.

\subsubsection{Panel Cointegration Tests}

If all the highlighted variables are stationary after their first difference, the long-term link between the variables can be checked using the [46-48] panel cointegration tests.

Based on the residuals' terms that existed in the [51] cointegration regression, the authors of $[46,47]$ tried to develop a number of statistics. By supposing a panel with $N$ countries, $T$ observations, and $m$ regressors $\left(V_{m}\right)$, refs. [46,47] considered the following regression equation:

$$
W_{i t}=\alpha_{i}+\lambda_{i} t+\sum_{j=1}^{m} \beta_{j, i} V_{j, i t}+\xi_{i t} ; \forall i=1, \ldots, N ; \quad \forall t=1, \ldots, T
$$

where $W_{i, t}$ and $V_{j, i, t}$ are integrated into order $1, \mathrm{I}(1)$.

The authors of $[46,47]$ also developed two series of panel cointegration tests. The first one, known as panel cointegration tests, relies on the intra-dimensional method and consists of four statistics: the panel ADF-statistic $\left(Z_{A D F}\right)$, panel rho-statistic $\left(Z_{\rho}\right)$, panel v- 
statistic $\left(Z_{v}\right)$, and panel PP-statistic $\left(Z_{p p}\right)$. These statistics combine the autoregressive (AR) coefficients from several nations to perform unit root tests related to the estimated residuals, while considering country heterogeneity and common temporal factors. The second one, known as group-mean panel cointegration tests, relies on the between-dimensional perspective that involves three statistics: the group ADF-statistic $\left(\widetilde{Z}_{A D F}\right),\left(\widetilde{Z}_{\rho}\right)$, group PPstatistic $\left(\widetilde{Z}_{p p}\right)$, and group rho-statistic. These statistics are derived from the individual mean autoregressive coefficients related to the residual unit root tests for each country (see [52] for further information). All seven tests confirm the non-existence of cointegration under the null hypothesis; however, the alternative hypothesis is provided by $H_{1}: \rho_{i}=\rho<1 ; \forall \mathrm{i}$, where $\rho_{i}$ is the AR factor of the residuals, given by the alternative hypothesis yielded by the next equation:

$$
\hat{\xi}_{i, t}=\rho_{i} \hat{\xi}_{i, t-1}+u_{i, t}
$$

The authors of [46] showed that all seven statistics have a standard normal distribution, which is indicated in the Brownian motions' independent movements when $\mathrm{T}$ and $\mathrm{N} \rightarrow \infty$ :

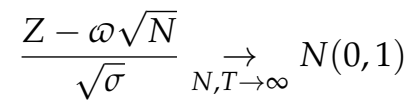

where $Z$ presents one of the seven statistics; $\omega$ and $\sigma$ are tabulated in [46].

The authors of [48] proposed the following form of the next regression equation:

$$
W_{i, t}=\alpha_{i}+\beta V_{i, t}+\xi_{i, t}
$$

where $W_{i, t}=\sum_{t=1}^{T} w_{i, t}, \mathrm{~V}_{i, t}=\sum_{t=1}^{T} v_{i, t} ; \quad \forall i=1, \ldots, N \forall t=1, \ldots, T$.

The test of [48] is based on the residual and variants of [53], noted by PP, and [49], noted by ADF. This test is given by:

$$
\hat{\xi}_{i, t}=\rho \hat{\xi}_{i, t-1}+\sum_{j=1}^{p} \varphi_{j} \Delta \hat{\xi}_{i, t-j}+\mu_{i, t, p}
$$

where $\mu_{i, t, p}$ are uncorrelated under the null hypothesis, implying that, for the non-cointegration, $\rho$ is chosen. Then, the statistical ADF test can be defined as:

$$
A D F=\frac{t_{A D F}+\frac{\sqrt{6 N \hat{\sigma}_{\mu}}}{2 \hat{\sigma}_{0 \mu}}}{\sqrt{\frac{\hat{\sigma}_{0 \mu}^{2}}{2 \hat{\sigma}_{\mu}^{2}}+\frac{3 \hat{\sigma}_{\mu}^{2}}{10 \hat{\sigma}_{0 \mu}^{2}}}} \underset{\text { under } H_{0}}{\rightarrow} N(0,1)
$$

where $t_{A D F}$ is the t-statictic of $\rho$ in Equation (11), and $\sigma_{0 \mu}$ is calculated from the covariance matrix $\Omega=\left[\begin{array}{cc}\sigma_{0 w}^{2} & \sigma_{0 w v} \\ \sigma_{0 w v} & \sigma_{0 v}^{2}\end{array}\right]$ of the bi-varied process $\left(w_{i, t}, v_{i, t}\right)^{\prime}$.

\subsubsection{FMOLS, DOLS and PMG Estimates}

Although the cointegrated vectors' OLS estimators are superconvergents with nonlinear models, their distribution is asymptotically biased, and depends on nuisance parameters associated with the existence of serial correlation (see [54-56]). Such issues, which appear in time series data, also appear in panel data, and they seem to be more pronounced when heterogeneity is present (see [56]).

As a result, methods of effective estimation must be used to conduct tests based on cointegrated vectors. Several strategies are available, including fully modified ordinary least squares (FMOLS), which was first proposed in [57], and the dynamic ordinary least squares (DOLS) method, proposed in [58,59]. The authors of [56] demonstrated that both approaches generate normally distributed estimators for panel data. According to these 
methods, it is indicated that OLS and FMOLS both have a small sample bias, though DOLS seems to surpass both estimators. The authors of $[55,60]$ obtained similar outcomes for the FMOLS method. Another intermediate estimator, called pooled mean group (PMG), was used in [61] in order to show the short-term dynamic specification that may differ from one country to another, while the long-term coefficients are forced to be the same, and involve both pooling and averaging.

The FMOLS estimator used in $[54,55]$ consists of solving the problem of the regressors' endogeneity. The work on this technique is based on the following equation:

$$
W_{i, t}=a_{i}+b_{i} V_{i, t}+\zeta_{i, t} \forall i=1, \ldots, N, \forall t=1, \ldots, T
$$

where $W_{i t}$ and $V_{i, t}$ are cointegrated with slopes $b_{i}$, and $b_{i}$ may or may not be homogeneous across $i$. Based on the ADF analysis, the transformation of Equation (13) are given by:

$$
W_{i, t}=a_{i}+b_{i} V_{i, t}+\sum_{k=-K_{i}}^{K_{i}} \gamma_{i, k} \Delta V_{i, t-k}+\zeta_{i, t} \forall i=1, \ldots, N, \forall t=1, \ldots, T
$$

The empirical work considers that $\xi_{i, t}=\left(\hat{\zeta}_{i, t}, \Delta V_{i, t}\right)$ and $\Omega_{i, t}=\lim _{T \rightarrow \infty} E\left[\frac{1}{T}\left(\sum_{t=1}^{T} \xi_{i, t}\right)\left(\sum_{t=1}^{T} \xi_{i, t}\right)^{\prime}\right]$ indicate the vector process's long-term covariance, and can be decomposed into $\Omega_{i}=$ $\Omega_{i}^{0}+\Gamma_{i}+\Gamma_{i}^{\prime}$ where $\Omega_{i}^{0}$ is the contemporaneous covariance and $\Gamma_{i}$ is a weighted sum of autocovariance.

According to the panel FMOLS technique, its estimator is calculated as follows:

$$
\hat{b}_{F M O L S}^{*}=\frac{1}{N} \sum_{i=1}^{N}\left[\left(\sum_{t=1}^{T}\left(V_{i, t}-\bar{V}_{i}\right)^{2}\right)^{-1}\left(\sum_{t=1}^{T}\left(V_{i, t}-\bar{V}_{i}\right) W_{i, t}^{*}-T \hat{\gamma}_{i}\right)\right]
$$

where $W_{i, t}^{*}=W_{i, t}-\bar{W}_{i}-\frac{\hat{\Omega}_{2,1, i}}{\hat{\Omega}_{2,2, i}} \Delta V_{i, t}$ and $\hat{\gamma}_{i}=\hat{\Gamma}_{2,1, i}+\hat{\Omega}_{2,1, i}^{0}-\frac{\hat{\Omega}_{2,1, i}}{\hat{\Omega}_{2,2, i}}\left(\hat{\Gamma}_{2,2, i}+\hat{\Omega}_{2,2, i}^{0}\right)$.

The DOLS estimator was originally described in [58] for the study of time series, and later used in $[56,62]$ for the study of panel data framework. This technique is based on the study of advanced and delayed values in a cointegrated relationship, in order to avoid the correlation problem between regressors and error terms.

According to the panel DOLS technique, its estimator is calculated as follows:

$$
\hat{b}_{D O L S}^{*}=\frac{1}{N} \sum_{i=1}^{N}\left[\left(\sum_{t=1}^{T} Z_{i, t} Z_{i, t}{ }^{\prime}\right)^{-1}\left(\sum_{t=1}^{T} Z_{i, t} \widetilde{W}_{i, t}\right)\right]
$$

where $Z_{i, t}=\left[V_{i, t}-\bar{V}_{i}, \Delta V_{i, t-K_{i}}, \ldots, \Delta V_{i, t+K_{i}}\right]$ is the regressors' vector, and $\widetilde{W}_{i, t}=W_{i, t}-\bar{W}_{i}$.

The difference between PMG and both FMOLS and DOLS is that the PMG estimator can, firstly, use the short-term dynamic specification to mark differences from country to another country, while the long-term coefficients are forced to be the same. Secondly, it can consider averaging separate estimates for each group in the panel, without considering potential homogeneity between groups. Based on this approach, the authors of [61] propose an ARDL model, ARDL $(p, q)$, given as:

$$
W_{i, t}=a_{i}+\sum_{k=1}^{p} b_{i, k} \cdot W_{i, t-k}+\sum_{s=0}^{q} \delta_{i, s} \cdot V_{i, t-s}+\varepsilon_{i, t}
$$

The cross-section countries and the time periods are, respectively, denoted by $i=1,2, \ldots, N$, and $t=1,2, \ldots, T . V_{i, t-s}$ is a vector of regressors for country $i, a_{i}$ represents the fixed effect, $b_{i, k}$ is the coefficient of the lagged dependent variables, $\delta_{i, s}$ are $(r \times 1)$ coefficient vectors, and the lag length of " $p$ " and " $q$ " is selected using the modified schwarz information criteria (SIC). 
The transformation of Equation (17) is given by the following re-parametrization:

$$
\Delta W_{i, t}=a_{i}+\phi_{i} W_{i, t-1}+\rho_{i} V_{i, t-1}+\sum_{k=1}^{p-1} b_{i, k}^{*} \cdot \Delta W_{i, t-k}+\sum_{s=0}^{q-1} \delta_{i, s}^{*} \cdot \Delta V_{i, t-s}+\varepsilon_{i, t}
$$

where $\phi_{i}=-\left(1-\sum_{k=1}^{p} b_{i, k}\right), \rho_{i}=\sum_{s=0}^{q} \delta_{i, s}, b_{i, k}^{*}=-\left(\sum_{m=k+1}^{p} b_{i, m}\right)$, and $\delta_{i, s}^{*}=-\left(\sum_{m=s+1}^{q} \delta_{i, m}\right)$.

\section{Econometric Results and Interpretations}

The results of the panel unit root tests are reported in Table 2. The outcomes of these tests show that, in the first difference, all panel variables are stationary at $5 \%$ significance. Thus, the findings show that all variables are integrated into order 1, I(1).

Table 2. Panel unit root test results in North African countries from 1971 to 2014.

\begin{tabular}{|c|c|c|c|c|}
\hline Method & & LNGDP & LNEC & $\mathrm{LNCO}_{2}$ \\
\hline \multicolumn{5}{|l|}{$\mathbf{L L C} \mathbf{t} *$} \\
\hline \multirow[t]{2}{*}{ (a) Level } & (with trend) & 0.76317 (0.7773) & $-1.87004(0.0307) * *$ & $-0.99203(0.1606)$ \\
\hline & (without trend) & $-1.83406(0.0333) * *$ & $-5.00237(0.0000) * *$ & $-3.93438(0.0000) * *$ \\
\hline \multirow[t]{2}{*}{ (b) First difference } & (with trend) & $-2.32732(0.0100) * *$ & $-6.77214(0.0000) * *$ & $-8.17930(0.0000) * *$ \\
\hline & (without trend) & $-2.57578(0.0050) * *$ & $-6.60241(0.0000) * *$ & $-8.32372(0.0000) * *$ \\
\hline \multicolumn{5}{|l|}{ IPS W-stat } \\
\hline \multirow[t]{2}{*}{ (a) Level } & (with trend) & $0.40906(0.6588)$ & $-0.78619(0.2159)$ & $-2.30766(0.0105) * *$ \\
\hline & (without trend) & $-0.18025(0.4285)$ & $-3.09734(0.0010) * *$ & $-2.70883(0.0034)^{* *}$ \\
\hline \multirow[t]{2}{*}{ (b) First difference } & (with trend) & $-5.99199(0.0000) * *$ & $-8.47429(0.0000) * *$ & $-9.83138(0.0000)^{* *}$ \\
\hline & (without trend) & $-6.79125(0.0000) * *$ & $-7.93134(0.0000) * *$ & $-10.1512(0.0000)^{* *}$ \\
\hline \multicolumn{5}{|l|}{ MW Fisher-Chi-square } \\
\hline \multirow[t]{2}{*}{ (a) Level } & (with trend) & $9.45382(0.4896)$ & $-11.9570(0.2879) *$ & $22.3713(0.0133) * *$ \\
\hline & (without trend) & $15.8019(0.1054)$ & $-35.4562(0.0010)^{* *}$ & $23.7616(0.0083) * *$ \\
\hline \multirow[t]{2}{*}{ (b) First difference } & (with trend) & $53.9304(0.0000)$ ** & $77.8957(0.0000) * *$ & $93.0935(0.0000) * *$ \\
\hline & (without trend) & $66.2480(0.0000) * *$ & $78.3385(0.0000) * *$ & $105.125(0.0000) * *$ \\
\hline \multicolumn{5}{|l|}{ Hadri Z-stat } \\
\hline \multirow[t]{2}{*}{ (a) Level } & (with trend) & $-3.20294(0.0007) * *$ & $-6.01093(0.0000) * *$ & $-4.11983(0.0000)^{* *}$ \\
\hline & (without trend) & $-10.0737(0.0000) * *$ & $-9.69801(0.0000) * *$ & $-10.2798(0.0000) * *$ \\
\hline \multirow[t]{2}{*}{ (b) First difference } & (with trend) & $-1.46795(0.0711) *$ & $-2.97203(0.0015) * *$ & $-1.57339(0.0000)$ ** \\
\hline & (without trend) & $-0.85204(0.1971)$ & $-5.79565(0.0000) * *$ & $-0.35142(0.3626)$ \\
\hline
\end{tabular}

Note: LLC, IPS, MW-Fisher, and Hadri tests consider the absence of stationarity in the null hypothesis, and * and ** indicate levels of statistical significance at $10 \%$ and $5 \%$, respectively. According to the authors of [63], the probabilities of the Fisher test were determined based on an asymptotic $\chi^{2}$ distribution. Asymptotic normality is considered for all others tests. The modified Schwarz information criteria (SIC) was used to select the appropriate lag length.

Given that all highlighted variables were stationary after their first difference, the long-term link between variables can be checked using the [46-48] panel cointegration tests.

The outcomes of these cointegration tests are reported, respectively, in Tables 3 and 4. These inspect the existence of heterogeneity in the studied panels, in which heterogeneous slope coefficients, fixed effects, and individual specific deterministic trends are allowed in [46,47]'s test, and only fixed effects used in [48]'s test.

Table 3. Residual cointegration test results from [46,47] (LNGDP as an endogenous variable).

\begin{tabular}{cccccc}
\hline Method & Statistic Test & Prob & Method & Statistic Test & Prob \\
\hline Within-Dimension & & & Between-Dimension & \\
\hline Panel v-stat & 2.197592 & $0.0140^{* *}$ & & & \\
\hline Panel r-stat & -3.000778 & $0.0013^{* *}$ & Group r-stat & -1.830518 & $0.0336^{* *}$ \\
\hline Panel PP-stat & -3.195549 & $0.0007^{* *}$ & Group PP-stat & -2.626453 & $0.0043^{* *}$ \\
\hline Panel ADF-stat & -1.304750 & 0.0960 & Group ADF-stat & 0.697912 & 0.7574 \\
\hline
\end{tabular}

Note: The null hypothesis indicates the absence of cointegration between studied variables. ${ }^{* *}$ denotes a $5 \%$ statistical significance level. 
Table 4. Residual cointegration test results from [48] (LNGDP as an endogenous variable).

\begin{tabular}{ccc}
\hline Method & Statistic Test & Prob \\
\hline ADF & $-4.427797^{* *}$ & 0.0000 \\
\hline
\end{tabular}

Note: The null hypothesis indicates the absence of cointegration between studied variables. ${ }^{* *}$ denotes a $5 \%$ statistical significance level.

Considering heterogeneity, a panel cointegration model, in which economic growth (GDP) is considered as a dependent variable, was used in the present work, as follows:

$$
L N G D P_{i, t}=\alpha_{i}+\beta_{i} L N E C_{i, t}+\delta_{i} L N C O 2_{i, t}+\varepsilon_{i, t} ; \forall i=1, \ldots, N ; \quad \forall t=1, \ldots, T
$$

According to the results of the $[46,47]$ heterogeneous panel tests, the null hypothesis of no cointegration can be rejected at the $5 \%$ significance level, except for the ADF-stat, as shown in Table 3. Confirmation of the null hypothesis, indicating no cointegration, was also shown by the residual panel cointegration tests of [48].

This finding leads us to conclude the presence of a panel long-term link between these three variables.

The findings of the panel cointegration estimates are shown in Table 5. Regarding the FMOLS and DOLS estimates, our models propose the regression presented in Equation (20), where GDP and EC slopes are denoted as $b_{i}$, and GDP and $\mathrm{CO}_{2}$ slopes are denoted as $\delta_{i}$, which may or may not be homogeneous across country $i$. Regarding the PMG estimator, the general equation (Equation (18)) given in [61] is based on the model ARDL $(1,1,1)$.

Table 5. FMOLS, DOLS, and PMG estimates of North African countries from 1971 to 2014.

\begin{tabular}{ccccccc}
\hline \multirow{2}{*}{ Country } & \multicolumn{3}{c}{ LNEC } & \multicolumn{3}{c}{ LNCO $_{2}$} \\
\cline { 2 - 7 } & FMOLS & DOLS & PMG & FMOLS & DOLS & PMG \\
\hline Egypt & $0.302882^{* *}$ & $0.217838^{* *}$ & $0.398099^{* *}$ & $0.668412^{* *}$ & $0.744884^{* *}$ & $0.564195^{* *}$ \\
Libya & $0.488978^{* *}$ & $0.311123^{*}$ & $0.560619^{* *}$ & -0.016155 & 0.035853 & -0.068542 \\
Tunisia & $1.900196^{* *}$ & $2.053885^{* *}$ & $1.623900^{* *}$ & $-0.854048^{* *}$ & $-1.025748^{* *}$ & $-0.584337^{* *}$ \\
Algeria & $0.311024^{* *}$ & $0.414824^{* *}$ & $0.269849^{* *}$ & -0.057916 & -0.022819 & 0.063728 \\
Morocco & $1.179060^{* *}$ & $1.166619^{* *}$ & $1.112170^{* *}$ & -0.121162 & -0.115239 & -0.073349 \\
Panel & $1.242549^{* *}$ & $1.249666^{* *}$ & $1.237309^{* *}$ & $-0.337334^{* *}$ & $-0.392698^{* *}$ & $-0.361694^{* *}$ \\
\hline
\end{tabular}

Note: ${ }^{*}$ and ${ }^{* *}$ denote $10 \%$ and $5 \%$ statistical significance levels, respectively.

Thus, the transformation of Equation (18) is given by:

$$
\operatorname{LNGDP}_{i, t}=a_{i}+\sum_{k=1}^{1} b_{i, k} \cdot \operatorname{LNGDP_{i,t-k}}+\sum_{s_{1}=0}^{1} \delta_{i, s_{1}} \cdot \operatorname{LNEC}_{i, t-s_{1}}+\sum_{s_{2}=0}^{1} \delta_{i, s_{2}} \cdot \operatorname{LNCO}_{i, t-s_{2}}+\varepsilon_{i, t}
$$

Starting with the relationship running from EC to GDP, all countries' data produced acceptance at the 5\% and 10\% levels in the FMOLS, DOLS and PMG estimates between the individual country tests. Furthermore, GDP and EC have a positive association. This suggests that if EC grows, at least these five countries' GDP will grow. Regarding the relationship running from $\mathrm{CO}_{2}$ to GDP, these countries' data produced acceptance at the $5 \%$ level for the three estimators (FMOLS, DOLS and PMG), except for Libya, Algeria, and Morocco. Moreover, the results showed a negative relationship between GDP and $\mathrm{CO}_{2}$ for all countries, except the estimators' values of FMOLS and PMG related to Egypt and Algeria, and the estimators' values of DOLS concerning Egypt and Libya. Based on the total panel results, it can be seen that strong relationships, which run from EC to GDP and from $\mathrm{CO}_{2}$ to GDP, were overwhelmingly accepted. In addition, the coefficients estimated by FMOLS, DOLS, and PMG, running from EC to GDP, were, respectively, 1.242549, 1.249666, and 1.237309. In addition, the coefficients estimated by FMOLS, DOLS and PMG, running from $\mathrm{CO}_{2}$ to GDP, were, respectively, $(-0.337334),(-0.392698)$, and $(-0.361694)$ for the pool of all five countries. Regarding the FMOLS estimators, we found that an increase 
in energy consumption by $1 \%$ leads to an increase GDP by $1.242549 \%$; additionally, an increase in $\mathrm{CO}_{2}$ emissions by $1 \%$ leads to decrease GDP by $0.337334 \%$ in the pooled region. Moreover, using DOLS estimators' approximate estimates, we found that a $1 \%$ increase in energy consumption correlates to a $1.249666 \%$ rise in GDP, and that a $1 \%$ in $\mathrm{CO}_{2}$ emissions leads to a $0.392698 \%$ decrease in GDP in the pool of all countries. On the other hand, the work on the PMG estimators showed that a $1 \%$ increase in energy consumption increases GDP by $1.237309 \%$, while a $1 \%$ rise in $\mathrm{CO}_{2}$ emissions decreases GDP by $0.361694 \%$ in the pool of all countries.

In general, the coefficients are statistically significant. This finding suggests that, in this circumstance, a more aggressive energy conservation program should be adopted [64]. In this situation, public and monetary policymakers need to comprehend the connection between GPD and EC, since relative changes in energy use are directly related to relative changes in output and income [65]. The authors of [66-70] showed that increased energy consumption results in increased income and outputs, for both positive and negative factors. These findings show that $\mathrm{CO}_{2}$ emissions, $\mathrm{EC}$, and energy efficiency in underdeveloped countries are significantly lower than in developed ones. However, total energy demand will rapidly increase with economic progress. Furthermore, developing countries have consistently attempted to reduce $\mathrm{CO}_{2}$ emissions by supporting new energy technology, transforming the electricity system, and implementing clean development processes to achieve economic expansion while conserving energy, mitigating emissions, and responding to climate change worldwide [31]. Empirical findings also suggest that appropriate and prudent policies are required in order to control $\mathrm{CO}_{2}$ emissions other than energy consumption. The ultimate impact of $\mathrm{CO}_{2}$ emissions will help to support sustainable economic growth and maturation, as well as largely improving region welfare [33].

\section{Conclusions and Policy Implications}

This paper examines the impact of energy consumption (EC) and $\mathrm{CO}_{2}$ emissions on economic development (GDP) in five North African countries, from 1971 to 2014. To define what matters, a panel cointegration analysis, based firstly on FMOLS and DOLS estimates for the long-term relationship to deal with the endogeneity bias in regressors and the heterogeneity in countries, and secondly dependent on the PMG estimator, which involves both pooling and averaging for a dynamic specification using the ARDL approach, was employed.

Based on the empirical findings, there is evidence of a long-term panel connection between these three variables, which shows that EC plays a vital role in increasing GDP in the studied economies, although there is a negative impact on the environment as more pollution is caused. Indeed, as part of a comprehensive discussion of environmental development, the use of fossil fuels, which contributes to GHG emissions, has been gradually expanding in the area since the 1990s, resulting in simultaneous increases in GHG emissions. Consequently, these countries should increase energy productivity, the implementation of energy savings projects, and energy conservation to achieve GDP expansion and boost their investments in energy sectors, as well as mitigating pollutant emissions. Mitigation activities usually entail increasing the use of renewable energy to replace and reduce the huge proportion of total energy produced by fossil fuel burning. Energy efficiency and conservation activities that may decrease the global amount of fossil fuel utilization, especially regarding electricity consumption, are also part of the mitigation efforts. In the North African region, there is a huge potential for wind and solar resources, as well as hydro resources in Morocco specifically. These countries can, therefore, substitute the partial use of fossil fuel with the consumption of renewable energy. In other words, they can create a suitable combination of fossil energy and renewable energy that allows them to maximize economic growth and protect the environment.

In a future work, it would be interesting to deal with mixed energy; this would consist of trying to set an efficient combination of renewable energy and fossil energy. 
This combination would be ideal for achieving economic growth under the condition of environmental protection.

Author Contributions: Conceptualization, S.F.; methodology, M.K. and Y.G.; software, S.F.; validation, S.F., M.K. and Y.G.; formal analysis, S.F.; investigation, M.K.; resources, S.F.; data curation, S.F.; writing — original draft preparation, S.F. and Y.G.; writing—review and editing, M.K.; visualization, S.F.; supervision, M.K.; project administration, M.K. and S.F.; funding acquisition, M.K. All authors have read and agreed to the published version of the manuscript.

Funding: This research received no external funding.

Data Availability Statement: The datasets used during the current study are available from the corresponding or first author on reasonable request.

Conflicts of Interest: The authors declare no conflict of interest.

\section{References}

1. Alagidede, P.; Adu, G.; Frimpong, P.B. The Effect of Climate Change on Economic Growth: Evidence from Sub-Saharan Africa. Environ. Sci. Pollut. Res. 2016, 18, 417-436. [CrossRef]

2. Ang, J.B. $\mathrm{CO}_{2}$ Emissions, Energy Consumption, and Output in France. Energy Policy 2007, 35, 4772-4778. [CrossRef]

3. Arouri, M.H.; Ben Youssef, A.; M'Henni, H.; Rault, C. Energy Consumption, Economic Growth and $\mathrm{CO}_{2}$ Emissions in Middle East and North African Countries. Energy Policy 2012, 45, 342-349. [CrossRef]

4. Gardiner, R.; Hajek, P. Interactions among Energy Consumption, $\mathrm{CO}_{2}$, and Economic Development in European Union Countries. Sustain. Dev. 2020, 28, 723-740. [CrossRef]

5. Soytas, U.; Sari, R.; Ewing, B.T. Energy Consumption, Income, and Carbon Emissions in the United States. Ecol. Econ. 2007, 62, 482-489. [CrossRef]

6. Aye, G.C.; Edoja, P.E. Effect of Economic Growth on $\mathrm{CO}_{2}$ Emission in Developing Countries: Evidence from a Dynamic Panel Threshold Model. Cogent Econ. Financ. 2017, 5, 1-22. [CrossRef]

7. World Bank Development Report (WDR). Energy Sector Management Assistance Program: Potentials of Energy Integration in Mashreq and Neighboring Countries; World Bank Development Report: Washington, DC, USA, 2010.

8. Ahmed, S.M.; Dougherty, W. Climate Change and the Environment. In Unlocking North Africa's Potential through Regional Integration: Challenges and Opportunities; Santi, E., Ben Romdhane, S., Shaw, W., Eds.; African Development Bank (AfDB) Group, Temporary Relocation Agency (TRA): Tunis-Belvedere, Tunisia, 2012.

9. Coondoo, D.; Dinda, S. Causality between Income and Emission: A Country Group Specific Econometric Analysis. Ecol. Econ. 2002, 40, 351-367. [CrossRef]

10. Hamilton, C.; Turton, H. Determinants of Emissions Growth in OECD Countries. Energy Policy 2002, 30, 63-71. [CrossRef]

11. Liu, X. Explaining the Relationship between $\mathrm{CO}_{2}$ Emissions and National Income-The Role of Energy Consumption. Econ. Lett. 2005, 87, 325-328. [CrossRef]

12. Richmond, A.K.; Kaufmann, R.K. Is There a Turning Point in the Relationship between Income and Energy Use and/or Carbon Emissions? Ecol. Econ. 2006, 56, 176-189. [CrossRef]

13. Huang, B.N.; Hwang, M.J.; Yang, C.W. Causal Relationship between Energy Consumption and GDP Growth Revisited: A Dynamic Panel Data Approach. Ecol. Econ. 2008, 67, 41-54. [CrossRef]

14. Apergis, N.; Payne, J.E. $\mathrm{CO}_{2}$ Emissions, Energy Usage and Output in Central America. Energy Policy 2009, 37, 3282-3286. [CrossRef]

15. Akbostanci, E.; Türüt-Aşik, S.; Tunç, G.I. The Relationship between Income and Environment in Turkey: Is There an Environmental Kuznets Curve? Energy Policy 2009, 37, 861-867. [CrossRef]

16. Soytas, U.; Sari, R. Energy Consumption, Economic Growth, and Carbon Emissions: Challenges Faced by an EU Candidate Member. Ecol. Econ. 2009, 68, 1667-1675. [CrossRef]

17. Ozturk, I.; Acaravci, A. $\mathrm{CO}_{2}$ Emissions, Energy Consumption and Economic Growth in Turkey. Renew. Sustain. Energy Rev. 2010, 14, 3220-3225. [CrossRef]

18. Zhang, X.P.; Cheng, X.M. Energy Consumption, Carbon Emissions, and Economic Growth in China. Ecol. Econ. 2009, 68, 2706-2712. [CrossRef]

19. Chang, C.C. A Multivariate Causality Test of Carbon Dioxide Emissions, Energy Consumption and Economic Growth in China. Appl. Energy 2010, 87, 3533-3537. [CrossRef]

20. Acaravci, A.; Ozturk, I. On the Relationship between Energy Consumption, $\mathrm{CO}_{2}$ Emissions and Economic Growth in Europe. Energy 2010, 35, 5412-5420. [CrossRef]

21. Apergis, N.; Payne, J.E. The Emissions, Energy Consumption, and Growth Nexus: Evidence from the Commonwealth of Independent States. Energy Policy 2010, 38, 650-655. [CrossRef]

22. Fodha, M.; Zaghdoud, O. Economic Growth and Pollutant Emissions in Tunisia: An Empirical Analysis of the Environmental Kuznets Curve. Energy Policy 2010, 38, 1150-1156. [CrossRef] 
23. Narayan, P.K.; Narayan, S. Carbon Dioxide Emissions and Economic Growth: Panel Data Evidence from Developing Countries. Energy Policy 2010, 38, 661-666. [CrossRef]

24. Al-mulali, U. Oil Consumption, $\mathrm{CO}_{2}$ Emission and Economic Growth in MENA Countries. Energy 2011, 36, 6165-6171. [CrossRef]

25. Hossain, M.S. Panel Estimation for $\mathrm{CO}_{2}$ Emissions, Energy Consumption, Economic Growth, Trade Openness and Urbanization of Newly Industrialized Countries. Energy Policy 2011, 39, 6991-6999. [CrossRef]

26. Niu, S.; Ding, Y.; Niu, Y.; Li, Y.; Luo, G. Economic Growth, Energy Conservation and Emissions Reduction: A Comparative Analysis based on Panel Data for 8 Asian-Pacific Countries. Energy Policy 2011, 39, 2121-2131. [CrossRef]

27. Wang, S.S.; Zhou, D.Q.; Zhou, P.; Wang, Q.W. $\mathrm{CO}_{2}$ Emissions, Energy Consumption and Economic Growth in China: A Panel Data Analysis. Energy Policy 2011, 39, 4870-4875. [CrossRef]

28. Farhani, S.; Ben Rejeb, J. Energy Consumption, Economic Growth and $\mathrm{CO}_{2}$ Emissions: Evidence from Panel Data for MENA Region. Int. J. Energy Econ. Policy 2012, 2, 71-81.

29. Al-mulali, U.; Che Sab, C.N.B. The Impact of Energy Consumption and $\mathrm{CO}_{2}$ Emission on the Economic Growth and Financial Development in the Sub Saharan African Countries. Energy 2012, 39, 180-186. [CrossRef]

30. Shahbaz, M.; Lean, H.H.; Shabbir, M.S. Environmental Kuznets Curve hypothesis in Pakistan: Cointegration and Granger causality. Renew. Sustain. Energy Rev. 2012, 16, 2947-2953. [CrossRef]

31. Chandran, V.G.R.; Tang, C.F. The Dynamic Links between $\mathrm{CO}_{2}$ Emissions, Economic Growth and Coal Consumption in China and India. Appl. Energy 2013, 104, 310-318. [CrossRef]

32. Lim, K.-M.; Lim, S.-Y.; Yoo, S.-H. Oil Consumption, $\mathrm{CO}_{2}$ Emission, and Economic Growth: Evidence from the Philippines. Sustainability 2014, 6, 967-979. [CrossRef]

33. Azam, M.; Khan, A.Q.; Bin Abdullah, H.; Muhammad Ejaz Qureshi, M.E. The Impact of $\mathrm{CO}_{2}$ Emissions on Economic Growth: Evidence from Selected Higher $\mathrm{CO}_{2}$ Emissions Economies. Environ. Sci. Pollut. Res. 2016, 23, 6376-6389. [CrossRef]

34. Al-mulali, U.; Che Sab, C.N.B. The impact of coal consumption and $\mathrm{CO}_{2}$ emission on economic growth. Energy Sources B Econ. Plan. Policy 2018, 13, 218-223. [CrossRef]

35. Bhat, J.A. Renewable and Non-renewable Energy Consumption-Impact on Economic Growth and $\mathrm{CO}_{2}$ Emissions in Five Emerging Market Economies. Environ. Sci. Pollut. Res. 2018, 25, 35515-35530. [CrossRef]

36. Lin, F.-L.; Inglesi-Lotz, R.; Chang, T. Revisit Coal Consumption, $\mathrm{CO}_{2}$ Emissions and Economic Growth nexus in China and India using a Newly Developed Bootstrap ARDL Bound Test. Energy Explor. Exploit. 2018, 36, 450-463. [CrossRef]

37. Dong, K.; Sun, R.; Li, H.; Liao, H. Does Natural Gas Consumption Mitigate $\mathrm{CO}_{2}$ Emissions: Testing the Environmental Kuznets Curve Hypothesis for 14 Asia-Pacific Countries. Renew. Sustain. Energy Rev. 2018, 94, 419-429. [CrossRef]

38. Mardani, A.; Streimikiene, D.; Cavallaro, F.; Loganathan, N.; Khoshnoudi, M. Carbon Dioxide $\left(\mathrm{CO}_{2}\right)$ Emissions and Economic Growth: A Systematic Review of Two Decades of Research from 1995 to 2017. Sci. Total Environ. 2019, 649, 31-49. [CrossRef] [PubMed]

39. Yusuf, A.M.; Abubakar, A.B.; Mamman, S.O. Relationship between Greenhouse Gas Emission, Energy Consumption, and Economic Growth: Evidence from Some Selected Oil-Producing African Countries. Environ. Sci. Pollut. Res. 2020, 27, 15815-15823. [CrossRef] [PubMed]

40. Islam, M.M.; Alharthi, M.; Murad, M.W. The Effects of Carbon Emissions, Rainfall, Temperature, Inflation, Population, and Unemployment on Economic Growth in Saudi Arabia: An ARDL Investigation. PLoS ONE 2021, 16, e0248743. [CrossRef] [PubMed]

41. Máté, D.; Novotny, A.; Meyer, D.F. The Impact of Sustainability Goals on Productivity Growth: The Moderating Role of Global Warming. Int. J. Environ. Res. Public Health 2021, 18, 11034. [CrossRef] [PubMed]

42. Levin, A.; Lin, C.F.; Chu, C.S. Unit Root Tests in Panel Data: Asymptotic and Finite-Sample Properties. J. Econom. 2002, 108, 1-24. [CrossRef]

43. Im, K.S.; Pesaran, M.H.; Shin, Y. Testing for Unit Roots in Heterogeneous Panels. J. Econom. 2003, 115, 53-74. [CrossRef]

44. Maddala, G.S.; Wu, S. A Comparative Study of Unit Root Tests with Panel Data and a New Simple Test. Oxf. Bull. Econ. Stat. 1999, 61, 631-652. [CrossRef]

45. Hadri, K. Testing for Stationarity in Heterogeneous Panel Data. Econom. J. 2000, 3, 148-161. [CrossRef]

46. Pedroni, P. Critical Values for Cointegration Tests in Heterogeneous Panels with Multiple Regressors. Oxf. Bull. Econ. Stat. 1999, 61, 653-670. [CrossRef]

47. Pedroni, P. Panel Cointegration: Asymptotic and Finite Sample Properties of Pooled Time Series Tests with an Application to the PPP Hypothesis. Econom. Theory 2004, 20, 597-625. [CrossRef]

48. Kao, C. Spurious Regression and Residual-Based Tests for Cointegration in Panel Data. J. Econom. 1999, 90, 1-44. [CrossRef]

49. Dickey, D.A.; Fuller, W.A. Distribution of the Estimators for AutoRegressive Time Series with a Unit Root. J. Am. Stat. Assoc. 1979, 74, 427-431.

50. Kwiatkowski, D.; Phillips, P.C.B.; Schmidt, P.; Shin, Y. Testing the Null Hypothesis of Stationarity Against the Alternative of a Unit Root: How Sure Are We That Economic Time Series Have a Unit Root? J. Econom. 1992, 54, 159-178. [CrossRef]

51. Engle, R.F.; Granger, C.W.J. Co-integration and Error Correction: Representation, Estimation, and Testing. Econometrica 1987, 55, 251-276. [CrossRef]

52. Farhani, S.; Ben Rejeb, J. Link between Economic Growth and Energy Consumption in over 90 Countries. Interdis. J. Contem. Res. Bus. 2012, 3, 282-297. 
53. Phillips, P.C.B.; Perron, P. Testing for a Unit Root in Time Series Regressions. Biometrika 1988, 75, 335-346. [CrossRef]

54. Pedroni, P. Fully Modified OLS for Heterogeneous Cointegrated Panels. In Advances in Econometrics: Nonstationary Panels, Panel Cointegration, and Dynamic Panels; Baltagi, B.H., Fomby, T.B., Hill, R.C., Eds.; Emerald Group Publishing Ltd.: Bingley, UK, 2001; Volume 15, pp. 93-130.

55. Pedroni, P. Purchasing Power Parity Tests in Cointegrated Panels. Rev. Econ. Stat. 2001, 83, 727-731. [CrossRef]

56. Kao, C.; Chiang, M.H. On the Estimation and Inference of a Cointegrated Regression in Panel Data. In Advances in Econometrics: Nonstationary Panels, Panel Cointegration, and Dynamic Panels; Baltagi, B.H., Fomby, T.B., Hill, R.C., Eds.; Emerald Group Publishing Ltd.: Bingley, UK, 2001; Volume 15, pp. 179-222.

57. Phillips, P.C.B.; Hansen, B.E. Statistical Inference in Instrumental Variables Regression with I(1) Processes. Rev. Econ. Stud. 1990, 57, 99-125. [CrossRef]

58. Saikkonen, P. Asymptotically Efficient Estimation of Cointegration Regressions. Econom. Theory 1991, 7, 1-21. [CrossRef]

59. Stock, J.H.; Watson, M.W. A Simple Estimator of Cointegrating Vectors in Higher Order Integrated Systems. Econometrica 1993, 61, 783-820. [CrossRef]

60. Phillips, P.C.B.; Moon, H.R. Linear Regression Limit Theory for Nonstationary Panel Data. Econometrica 1999, 67, 1057-1112. [CrossRef]

61. Pesaran, M.H.; Shin, Y.; Smith, R.P. Pooled Mean Group Estimation of Dynamic Heterogeneous Panels. J. Am. Stat. Assoc. 1999, 94, 621-634. [CrossRef]

62. Mark, N.C.; Sul, D. Cointegration Vector Estimation by Panel DOLS and Long-run Money Demand. Oxf. Bull. Econ. Stat. 2003, 65, 655-680. [CrossRef]

63. Fisher, R. Statistical Methods for Research Workers; Oliver \& Boyd: Edinburgh, UK, 1932.

64. Ozturk, I.; Aslan, A.; Kalyoncu, H. Energy Consumption and Economic Growth Relationship: Evidence from Panel Data for Low and Middle Income Countries. Energy Policy 2010, 38, 4422-4428. [CrossRef]

65. Lee, C.C.; Chang, C.P.; Chen, P.F. Energy-Income Causality in OECD Countries Revisited: The Key Role of Capital Stock. Energy Econ. 2008, 30, 2359-2373. [CrossRef]

66. Lee, C.C. Energy Consumption and GDP in Developing Countries: A Cointegrated Panel Analysis. Energy Econ. 2005, $27,415-427$. [CrossRef]

67. Narayan, P.K.; Smyth, R. Energy Consumption and Real GDP in G7 Countries: New Evidence from Panel Cointegration with Structural Breaks. Energy Econ. 2008, 30, 2331-2341. [CrossRef]

68. Lee, C.C.; Chang, C.P. Energy Consumption and GDP Revisited: A panel Analysis of Developed and Developing Countries. Energy Econ. 2007, 29, 1206-1223. [CrossRef]

69. Lee, C.C.; Chang, C.P. Energy Consumption and Economic Growth in Asian Economies: A More Comprehensive Analysis using Panel Data. Resour. Energy Econ. 2008, 30, 50-65. [CrossRef]

70. Ozturk, I. A Literature Survey on Energy-Growth Nexus. Energy Policy 2010, 38, 340-349. [CrossRef] 